\title{
Challenges Facing Principals in the First Year at Their Schools
}

\author{
Adem Bayar \\ College of Education, Department of Educational Science, Amasya University, Turkey
}

Copyright (C) 2016 by authors, all rights reserved. Authors agree that this article remains permanently open access under the terms of the Creative Commons Attribution License 4.0 International License

\begin{abstract}
The aim of this study is to identify key challenges of practice that principals face. In line with this purpose, the researcher has employed a qualitative research methodology, interviewing principals working in Amasya district, over and above doing document analysis to collect detailed information concerning leadership and administration practice. After analyzing the collected data, the researcher has found that most participant principals have complained about their profession; therefore, they are more likely to leave their occupation. Furthermore, the principals have reported that they have faced the following challenges in schools: 1) violence, 2) families' negative attitudes towards school, 3) immigrant students/families from Syria and Iraq, 4) teacher unions (syndicalism), 5) teachers' attitudes and behaviors to principals, and 6) increasing of undesired behaviors in classroom/school. In the light of the above findings, the researcher has concluded that working as a principal in a school is more difficult than before. However, for the future of Turkey, Turkish policymakers, researchers, and educators should work together to minimize the negative impact of challenges and keep principals in the Turkish Education System.
\end{abstract}

Keywords New Principal, Challenges, Attrition, Retention, Leadership

\section{Introduction}

Schools are a type of organization that aims to improve teenagers' minds, teach them to become responsible adult, and prepare them for the future with new knowledge [1]. In order to reach these aims, schools need effective principals. Since, a healthy leader at work is the heart of an organization [2].

There is no doubt that the roles of principals in today's world of education have enlarged considerably [3]. Therefore, the demands on school principals have changed and the expectations from school principals are dramatically more than before [4-7]. In this regard, some researchers have conducted certain studies about principals and their instructional leadership roles. For instance, Viviane Robinson [8] has declared that principals have positive effects on students' learning and achievement. Since, the school principal creates a distinction in the school using the improvement process to directly or indirectly affects students' achievement [9-12]. Leithwood and Seashore-Louis [13] have affirmed that when principals focus on instruction and provide supportive working conditions in schools, they positively affect student-learning outcomes. At this point, it can be said that the principal is the most important and critical component of education in the school [14-16].

As can be understood from the above studies, principals play a key role for change and student achievement in schools. Thus, they are the most important and the first accountable person in the school. In other words, principals have more responsibility for the success of the students in the school.

Researchers, educators, and policymakers have paid attention to school principal recruitment, preparation, and professional development over the past several decades. As a result of these ongoing concerns, the numbers of studies about school principals have noticeably increased in the field of educational science [17-19]. In these continuing studies, Allison [20], Friedman [21], and Lindle [22] have found that school principals show concern about their unwelcome working conditions; that lead to high-level stress and burnout. Dağlı [23] has conducted a study and noted a 35,5\% burnout rate in school administrators.

In addition to what is mentioned above, some researchers have found that attrition among new school principals is pretty common [24]. A variety of studies in different countries have clearly shown that novice principals experience similar challenges in their role [25, 26, 27, 28]. They quickly lose their desire to continue in their role as the principal and are more likely to leave their profession. Within this context, many researchers in different countries have tried to explore the types of challenges school principals face in their schools. Borg and Riding [29] have affirmed that inadequate support, lack of resources, 
workload, unwelcome work conditions, and heavy responsibilities are the reasons of principals' stress. Cooper and Kelly [30] have identified that work overload, relations with staff, management of sources, local education authority (directorate of national education), and poor staff performance are the main job stressors of principals. Friedman [21] has found that principals have a lot of things to do as a leader of a school. They must participate in meetings, manage the needs of schools, find time to meet all their responsibilities, and do correctly all confused instructions. He [21] has also explained that parents are one of the most important reasons for principals' stress and burnout because of their unreasonable requests, acting offensively, keeping the principal occupied, and ignoring the expectations of the principal or staff. Others have similarly found that the common challenges for school principals involve long hours and a relentless workload, accompanied by demands from multiple and diverse stakeholders $[5,31,32,33]$.

The leadership style of the previous principal is another challenge for novice school principals [18,19]. School teachers and other employees compare the novice principal to the prior principal and resist new policies and procedures in the school. Also, there are technical challenges for school principals including the school budget, school construction, and applying new government initiatives [24]. Before starting their school administrative position, most principals worked as teachers in the schools [34,35]. After transitioning to the role as school principal, the social relationships between principals and teachers change [36]. Changing roles among people in school and not adapting to new roles may negatively affect school culture. At this point, it can be said that new social relationships are another challenge for principals. Consequently, novice principals frequently fight with the feelings of professional isolation and loneliness in the workplace [24].

From the above literature, new principals face a bunch of challenges in their schools. As a result, many are very close to leaving their administrative position. It should not be forgotten that they are also human beings [37]. When this issue has been considered from the economics and policy perspectives in education, losing school principals in their first-year as a professional is a concern for any country in the world. That is why; in an effort to counteract this serious issue and keep principals in their profession, there is an urgent need for further research to explore what types of problems new principals face in their role as school principals. The main purpose of this qualitative study is to explore and determine the challenges faced by novice principals.

\section{The Importance of Study}

Although many researchers around the world have accepted the importance of principals as agents of change and student achievement in schools, there remains inadequate research investigating challenges that new principals face in their role as principals in Turkish schools.
This gap in knowledge exemplifies a critical need for further research to determine these challenges from Turkish school principals' perspective. Consequently, this manuscript considers what has come to be known as "the challenges" of new school principals' in Turkey.

The results of this study guide to policymakers, researchers, and educators in Turkey, so that they might develop strategies to keep principals in the Turkish Education System. Moreover, this manuscript is instructive for the readers of the journal to learn more about one of the top issues in the field of educational administration. The findings will be of interest to principals themselves and teachers. In conducting this study, the researcher has hoped to elucidate these challenges that new principals face in their schools.

\section{Research Questions and Purpose of the Study}

The purpose of this study is to determine the challenges that novice school principals face. In this study, the researcher has investigated the experiences of novice school principals into their new role as a school principal. To do it, the researcher has focused on the challenges of practice that novice school principals experience. Hence, this research paper has addressed the following research questions throughout study:

1. What do novice principals think about their new occupation at their school?

2. What types of challenges do new principals face in their schools?

\section{Methodology}

The researcher has employed a qualitative research approach in this study to obtain detailed information about the research topic. Since, employing qualitative research approach is the most useful method to get in-depth data for any study [38, 39]. Similarly, Bogdan and Biklen [40] have declared that employing qualitative research approach provides more detailed knowledge to researchers about research topic based on the sense of the peoples' living styles, values, experiences, and worldview.

Phenomenologists are interested in the 'lived experience'. This type of research causes researchers to look at the 'shared lived experience' [41-42-43]. Since, the aim of this study is to explore the 'lived experiences' of the novice principals. The researcher has decided that phenomenology is the qualitative method of choice.

\section{Study Group}

According to the agreement between the Directorate of National Education and Amasya University, the researcher was assigned to provide some professional development activities to 200 new school principals in Amasya in the 2014-2015 academic years. Therefore, the researcher has reached out all new principals and asked them to brainstorm and provide their list of challenges that they face in their new 
position at schools. After collecting all written documents from the principals, the researcher has randomly selected and invited 20 new principals for interviews. However, 14 of them were volunteers to interview with the researcher. The researcher then visited them in their own schools. Thus, the study group consisted of 200 principals for the document analysis process and 14 principals for the interview process.

\section{Data Collection and Analysis}

In order to collect data, the researcher has used two techniques. First, the researcher has asked all new principals to write down what types of challenges they face in their administrative role. Second, the researcher has conducted semi-structured interviews with the 14 volunteer principals. Since, semi-structured interviews allow flexibility on some level to generate additional questions based on the answers of participants [44]. The researcher has scrutinized both national and international studies for creating interview questions. Then, the researcher has discussed all interview questions with three pedagogues and three principals on understandable and content validity. After that, the researcher has reached the final interview questions. Each interview was approximately 35 minutes, noted and transcribed verbatim. By doing so, the researcher has collected the data with the respect of new school principals' first-hand experience with their administrative positions.

The researcher has analyzed the collected data following: 1) getting the codes, 2) determining the themes, 3) organizing the codes and themes, and 4) identifying and interpreting of findings [45]. The researcher has named the participant principals as $\mathrm{P} 1, \mathrm{P} 2, \mathrm{P} 3, \mathrm{P} 4, \mathrm{P} 5, \mathrm{P} 6, \mathrm{P} 7, \mathrm{P} 8, \mathrm{P}$, $\mathrm{P} 10, \mathrm{P} 11, \mathrm{P} 12, \mathrm{P} 13$, and $\mathrm{p} 14$; used representative statements to the study as citation or quotation to delineate the main themes. The researcher has also employed "member checks", "adequate engagement in data collection", and "rich, thick descriptions" strategies to increase the reliability and validity of the data analysis process [43].

\section{Findings and Discussion}

First of all, the researcher has wanted to know that what novice principals think about their new positions. After analyzing all written documents from 200 principals and the collected data interviewing with the 14 principals, the researcher has come to know that most participant principals (148 out of 200) have complained about their professional role as principal. The researcher has also learned that 121 of them are more likely to leave their occupation. For instance, one of the principals said:

When I was a teacher one year ago, I was thinking that being a principal was so easy. However, I must admit that I was wrong. Since, you have more responsibilities when you are a principal. Honestly, I had more free time when I was a teacher; because, I just had to go to class. But, now, my working hours are from 7:30 am till 5:00 pm at weekdays. Even, I go to the school almost every Saturdays. Therefore, I am not happy as a principal. It is very upset to accept that I most probably will quit my administrative position in the near future (P1, 2015, personal communication).

The perspective of another participant principal is very similar to that of the above principal. He stated that:

As time goes on, we are getting more responsibilities in schools. However, meeting all of them is not possible in a limited time. This creates more stresses on me and I feel so tired when I am back home. Also, I need to manage all changes in my school and that makes me crazy sometimes. In fact, I miss my teaching days. Since, I had more free time and fewer responsibilities when I was a teacher. As a result, I am planning to resign my administrative role soon (P2, 2015, personal communication).

In a similar vein, one of the participant principals announced that:

Being a principal was my big dream when I was a teacher. However, the reality is absolutely different than theory. I was so idealist at the first weeks of school administration. In the process of time, I have lost my desire and enthusiasm. Since, I am fed up trying to convince teachers to do new things in my school. Most of them are opposed to my opinions and do not offer any different idea. They are just against me. Actually, I do not know what I should do and how I can overcome this issue. I just know that I am more upset than before and longing my teaching years. I will not fight with them and leave my administrative position in days to come $(P 11,2015$, personal communication).

This finding corresponds with the statement of Johnson [46], who underlined that principals are close to leaving their profession. Johnson [46] stated that "There are many reasons why principals voluntarily leave the positions they worked so hard to earn" (p. 21). At this point, unless there is enough support for principals, the turnover is high. Being a principal requires more responsibilities. Therefore, some of the participant principals complain about their work and are close to quitting their administrative positions.

Furthermore, the researcher has asked the participant principals what types of challenges they face in their schools. After analyzing all written documents from 200 principals and the collected data from the 14 interviewed principals, the researcher has found that the participant principals have faced the following challenges in schools: 1) violence, 2) families' negative attitudes towards school, 3) immigrant students/families from Syria and Iraq, 4) teacher unions (syndicalism), 5) teachers' attitudes and behaviors to principals, and 6) increasing of undesired behaviors in classroom/school. 
Table 1. Results of Document Analysis about What Types of Challenges Principals Face in Schools

\begin{tabular}{|c|c|c|c|c|}
\hline & Types of Challenges Principals Face in Schools & $\mathrm{f}$ & $\%$ & Sample Sentence \\
\hline 1 & Violence & 93 & 21 & $\begin{array}{c}\text { Violence negatively affects not only students but } \\
\text { also teachers in my school (p3). }\end{array}$ \\
\hline 2 & Families' negative attitudes towards school & 84 & 19 & $\begin{array}{c}\text { Unfortunately, some parents have negative } \\
\text { biases against us ( } 44) \text {. }\end{array}$ \\
\hline 3 & Immigrant students/families from Syria and Iraq & 79 & 18 & $\begin{array}{l}\text { Immigrant students and their families are one of } \\
\text { the biggest challenges in my school (P13). }\end{array}$ \\
\hline 4 & Teacher unions (syndicalism) & 78 & 17 & $\begin{array}{l}\text { Teacher unions are one of the most important } \\
\text { challenges for getting together teachers in my } \\
\text { school (P7). }\end{array}$ \\
\hline 5 & Teachers' attitudes and behaviors to principals & 69 & 15 & $\begin{array}{c}\text { Some of my colleagues cannot see me as the } \\
\text { principal of the school and still act like I am a } \\
\text { teacher (P8). }\end{array}$ \\
\hline \multirow[t]{2}{*}{6} & Increasing of undesired behaviors in classroom/school & 47 & 10 & $\begin{array}{l}\text { It is very hard to say that undesired behaviors } \\
\text { such as smoking, fighting, using a drug, and etc. } \\
\text { are more common than before }(P 9) \text {. }\end{array}$ \\
\hline & Total & 450 & 100 & \\
\hline
\end{tabular}

\section{Violence}

Some participant principals have reported that violence is one of the most serious challenges that they face in their new school. For instance, one of the principals announced:

We, as school leaders, have a bunch of problems to solve in schools. To me, violence is the most urgent one. Since, violence negatively affects not only students but also teachers in my school. If we want to increase students' academic achievement, we need to minimize violent events among students and against teachers in the school (P3, 2015, personal communication).

The perspective of another participant principal is very similar to that of the above principal. He said that:

School safety is one of the important points in today's education. Since, the numbers of violent events in schools among students or against teachers have been dramatically increased. Even though theoretically I know how to take away this issue in my school, I have not enough support from anyone such as teachers, parents, and so on. Honestly, I do not know how we reach academic achievement unless we solve this issue as a team (P11, 2015, personal communication).

This finding is coherent with the results of Volokh and Snell [47] and Brooks and Ekkarin [48] who pointed out that violence is one of the hardest issues in schools. Therefore, having safe school environment is very important to keep principals in their profession. Violence is the most serious issue in schools and negatively affects principals' desire to keep their career. Therefore, it can be stated that as violent events in schools decrease, principals are more likely to remain in their administrative position.

\section{Families' Negative Attitudes towards School}

The researcher has found that families' negative attitudes towards school negatively affect principals' desire to remain in their profession. One of the principals explained:

As you know, we cannot be successful without families' supports. Unfortunately, some parents have negative biases against us. As a result, they neither respect us nor participate in any activity in our school. I know I must convince them to visit our school more regularly. But, I really do not know how I can do it (P4, 2015, personal communication).

In a similar vein, one of the participant principals reported that:

Even though I have tried different ways to change some parents' opinion about school and education, they still keep their negative idea on us. For instance, I have invited them to talk face to face about their child; they do not show up so far. Worse, I have called them but they have not responded me and called me back. If we do not work together, we cannot reach the aims of our school. Then, they blame us by asking why their child's grades are not good enough. This takes away our will to work (P12, 2015 , personal communication).

This finding is consistent with the results of Günbayı and Akcan [49], who found that families' negative attitudes towards school are one of the most important challenges that principals frequently face. In today's Turkish Education System, there is an application that is called "complaint line". By this, families can complain teachers and principals to the Ministry of National Education. Also, some politicians in Turkey insult teachers and principals in their speeches. Because of these things, families' might not care about teachers and principals. Also, their attitudes towards school might be affected negatively.

\section{Immigrant Students/Families from Syria and Iraq}

Some participant principals have identified that immigrant students and families from Syria and Iraq are another 
challenge in their school. One of the principals, for example, declared that:

I individually believe that we should open the doors for immigrant students. However, most of them do not know Turkish and we do not know their mother language. In this case, how we teach them or how they learn in Turkish instruction. Another important point is that there are some cultural differences between them and us. So, this is another issue to think about (P5, 2015, personal communication).

The perspective of another participant principal is very similar to that of the above principal. She pointed out that:

As you know nowadays many immigrant people are coming to Turkey. Of course, they are welcome; but bring some educational problems with themselves. First of all, we need to ask ourselves that whether or not we are ready for immigrant students' education in Turkey. Although, their moms are very interested in their children' education and often come to our regular parent meetings, we do not understand each other because of speaking different languages. In addition, most of the immigrant students experience war in their home country; therefore, have psychological problems. This creates some discipline problems in classrooms and the school. As a result, immigrant students and their families are one of the biggest challenges in my school (P13, 2015 , personal communication).

When the Turkish literature was reviewed, there was not any study about the effects of immigrant students/families from Syria and Iraq on principals. The reason for this could be that Turkey is a new participant in assisting Syrian and Iraqi immigrant students and their families. On the other hand, many Western countries have experience about immigrants; therefore, international researchers have noted that immigrant students/families is a challenge for schools [50]. Thus, building partnerships with immigrant parents is very important [51]. The findings of this study clearly show that we, Turkey, are not exactly ready to educate immigrant students from Syria and Iraq. Moreover, there is not any effective educational policy about this challenge.

\section{Teacher Unions (Syndicalism)}

The participant principals have reported that they face challenges with teacher unions (syndicalism). For instance, one of the principals clarified that:

Each teacher union in Turkey is related to one political party. Hence, it is very upset to say that having common agreements among teachers is very difficult in Turkey. Consequently, managing and bringing them to common ground are not so easy every time (P6, 2015, personal communication).

The perspective of another principal is very similar to that of the above principal. She saw teacher unions as another serious challenge by saying that:

$$
\begin{aligned}
& \text { As far as I am concerned, teacher unions are one of } \\
& \text { the most important challenges to put teachers } \\
& \text { together in my school. Since, teachers have been } \\
& \text { gone to pieces by teacher unions. So, all of them have } \\
& \text { some biases against their colleagues who are the } \\
& \text { members of another teacher union. I know 'many } \\
& \text { hands make light work' but I am not sure exactly how } \\
& \text { we can come together with the reality of syndicalism } \\
& \text { in Turkey (P7, 2015, personal communication). }
\end{aligned}
$$

This finding is coherent with the results of Yildırım [16], who asserted that teacher unions are another challenge for principals in their school. At this point, even though some researchers have stressed the necessity and the importance of teacher unions on education [52], some have revealed the negative results of syndicalism on education [53]. In Turkey, all teacher unions are related to different political parties and most unions propagandize their political views in schools.

\section{Teachers' Attitudes and Behaviors to Principals}

The researcher has also found that teachers' attitudes and behaviors towards principals deeply affect principals. For instance, one of the participant principals stated that:

I was working as a teacher last year. However, I have been assigned as the principal of the same school for now. Unfortunately, some of my colleagues cannot see me as the principal of the school and still act like I am a teacher. That undermines my authority in the school. In addition, some of my colleagues tend to compare my leadership style with the previous principal and are mostly against my administrative decisions. This deeply makes me upset (P8, 2015, personal communication).

The perspective of another principal is very similar to that of the above principal. He said that:

I, as a school leader, have some new projects in my mind. I have shared them with the teachers. However, some of them said that they miss their previous principal; therefore, do not want to be a part of any project in the school. I really do not know what the wrong is about me. I just want to do good things for students in my school. My hands are tied and I really feel bad because of their unfriendly actions (P14, 2015 , personal communication).

This finding corresponds with the results of Hart [19] and Loder and Spillane [36], who affirmed that style of the previous principal and changing of social relationships in school is one of the most serious challenges for principals. Teachers in Turkey have a lifetime job. Therefore, they might not care about principals.

\section{Increasing of Undesired Behaviors in Classroom/School}


The participant principals have also stated undesired behaviors have been dramatically increased in today's schools and this makes difficult everything more than before. In this regard, one of the principals endorsed that:

It is very hard to say that undesired behaviors such as smoking, fighting, using a drug, and etc. in schools are more common than before. Worse, there is not any effective educational policy to decrease these behaviors. I, as a principal of the school, have to battle with these problems by myself and this makes me very tired $(P 9,2015$, personal communication).

Another principal noted that:

Unfortunately, we have frequently faced undesired behaviors in the classroom and school. I, as the principal of my school, must overcome these behaviors to create more effective school climate and keep it. However, my success at this issue is questionable. Since, I am mostly alone. Unless we who are teachers, parents, the Directorate of National Education, and I- work as a team, overcoming these behaviors is not so easy (P10, 2015 , personal communication).

This finding is consistent with the results of Bayar and Kerns [54], who explained that undesired behaviors in classrooms/schools have been dramatically increased in schools. Cruickshank, Jenkins, and Metcalf [55] have also noted that undesired behaviors are a serious issue facing our schools today. Unfortunately, the sanctions available to impose on students for their undesirable behaviors are so limited in Turkey. Thus, students do not hesitate to show undesired behaviors in classrooms and schools.

\section{Conclusions}

In the light of the above findings, the researcher has come to the conclusion that working, as a principal in a school is more problematic than before. Therefore, the researcher personally believes that having effective leaders and more importantly keeping them in the schools are more difficult nowadays. In this sense, the researcher is interested in what types of challenges new principals face in schools. However, before answering this question, the researcher has wondered what novice principals think about their new leadership positions at their school. He has come to know that most of the novice principals are not happy and unfortunately are very close to quitting their position. The researcher has sought to know that what types of challenges these new principals face in schools and found that they have faced the following challenges in schools: 1) violence, 2) families' negative attitudes towards school, 3) immigrant students/families from Syria and Iraq, 4) teacher unions (syndicalism), 5) teachers' attitudes and behaviors to principals, and 6) increasing of undesired behaviors in classroom/school.

In conclusion, the researcher hopes that policymakers not only in Turkey but also in other countries will make some policies to help their principals in schools. More importantly, they can organize some mentoring programs for novice principals. Otherwise, having effective school leaders and keeping them in professionalism will be just a utopia.

Further research is needed to explore what can be done in order to overcome these determined challenges facing novice principals in schools. Also, some researchers could develop a questionnaire about these challenges and conduct a study with a large number of novice principals.

\section{Note}

An earlier version of this paper was presented as a paper presentation at the "VI. International Educational Administration Form", Cyprus International University, Lefkoşa, Cyprus, 5-7 November 2015.

\section{REFERENCES}

[1] Gedikoğlu T, Bülbül S. Liderlik standartları inanç boyutu açısından ilköğretim okulu müdürlerinin yönetsel yeterlikleri. Milli Eğitim Dergisi. 2009; 182: 123-149.

[2] Quick JC, Frey MM, Cooper CL. Guest editors' introduction: Managerial dimension of organizational health; The healthy leader at work. Journal of Management Studies. 2007; 44: 189-205.

[3] Cuban L. The Managerial Imperative and the Practice of Leadership in Schools. Albany: State University of New York Press, 1988.

[4] Crow GM. Complexity and the beginning principal in the United States: Perspectives on socialization. Journal of Educational Administration. 2006; 44:310-325.

[5] Lortie DC. School Principal. Managing in public: Chicago, IL: University of Chicago Press, 2009.

[6] Stevenson H. Moving towards, into and through principalship: Developing a framework for researching the career trajectories of school leaders. Journal of Educational Administration. 2006; 44: 408-420.

[7] Thomson P. School leadership: Heads on the Block? London, England: Routledge, 2009.

[8] Robinson V. Student-Centered Leadership. San Francisco, CA: Jossey- Bass, 2009.

[9] Grissom JA, Loeb S. Triangulating principal effectiveness: how perspectives of parents, teachers, and assistant principals identify the central importance of managerial skills. American Educational Research Journal. 2011; 48: 1091-1123.

[10] Hallinger P, Heck RH. Reassessing the principal's role in school effectiveness: A review of empirical research, 1980-1995. Educational Administration Quarterly. 1996;32(1): 5-44. 
[11] Louis KS, Kruse SD. Professionalism and Community: Perspectives on Reforming Urban Schools. Newbury Park, CA: Corwin Press, 1995.

[12] Robinson VMJ. Forging the links between distributed leadership and educational outcomes. Journal of Educational Administration. 2008;46: 241-256.

[13] Leithwood K, Seashore-Louis K. Linking Leadership to Student Learning. San Francisco, CA: Jossey- Bass, 2012.

[14] Cerit Y. İlköğretim okulu müdürlerinin hizmet yönelimli liderlik rollerini gerçekleștirme düzeyleri. Hacettepe Üniversitesi Eğitim Fakültesi Dergisi. 2007; 33: 88-98.

[15] Çelikten M. İdeal bir okul müdürü portresi. Eğitim Araştırmaları Dergisi. 2003; 13: 139-162.

[16] Yıldırım N. Okul müdürlerinin görevlerine ilişkin yaşadıkları sorunları çözme öyküleri 1şı̆̆ında denge roller. Ahi Evran Üniversitesi Kırşehir Eğitim Fakültesi Dergisi (KEFAD). 2011; 12(4): 55-79.

[17] Coburn CE. Shaping teacher sensemaking: School leaders and the enactment of reading policy. Educational Policy. 2005; 19: 476-509.

[18] Duke DL. School Leadership and Instructional Improvement. New York, NY: Random House, 1987.

[19] Hart AW. Principal Succession: Establishing Leadership in Schools. Albany: State University of New York Press, 1993.

[20] Allison DJ. Coping with stress in the principalship. Journal of Educational Administration. 1997; 35(1): 39-55.

[21] Friedman, IA. Burnout in school principals: role related antecedents. Social Psychology of Education. 2002; $5: 229-251$.

[22] Lindle JC. Trauma and stress in the principal's office: Systemic inquiry as coping. Journal of School Leadership. 2004; 14: 378-410.

[23] Dağlı A. Okul müdürlerinin tükenmişlik düzeyleri. Eğitim Araştırmaları Dergisi. 2006;25: 85-95.

[24] Spillane JP, Lee LC. Novice school principals' sense of ultimate responsibility: Problems of practice in transitioning to the principal's office. Educational Administration Quarterly. 2014; 50(3): 431-465.

[25] Hobson A, Brown E, Ashby P, Keys W, Sharp C, Benefield P. Issues for Early Headship: Problems and Support Strategies. Nottingham, England: National College for School Leadership, 2003.

[26] Walker K, Anderson K, Sackney L, Woolf J. Unexpected learning by neophyte principals: Factors related to success of first year principals in schools. Managing Global Transitions. 2003; 1(2): 195-213.

[27] Northfield S. The novice principal: Change and challenges. Canadian Journal of Educational Administration and Policy. 2013; 142: 158-182.

[28] Walker A, Haiyan Q. Beginning principals: Balancing at the top of the greasy pole. Journal of Educational Administration. 2006; 44(4): 297-309.

[29] Borg MG, Riding RC. Occupational stress and job satisfaction among school administrators. Journal of Educational Administration. 1993; 31:4-21.
[30] Cooper CL, Kelly M. Occupational stress in head teachers: A national UK study. British Journal of Educational Psychology. $1993 ; 63: 130-143$.

[31] MacBeath J, Gronn P, Opfer D, Lowden K, Ford C, Cowie M, O'brien J. (2009). The Recruitment and Retention of Headteachers in Scotland. Edinburgh, Scotland: Scottish Government, 2009.

[32] Portin B, Shen J, Williams RC. (1998). The changing principalship and its impact: Voices from principals. NASSP Bulletin. 1998; 82(602): 1-8.

[33] Williams RC, Portin BS. (1996). Challenges of School Leadership: The Changing Role Of The Principal. Olympia, WA: Association of Washington School Principals, 1996.

[34] Papa FC, Lankford H, Wyckoff J. The Attributes and Career Paths of Principals: Implications for Improving Policy. Albany: State University of New York Press, 2002.

[35] Ringel JS, Gates SM, Ghosh-Dastidar B, Brown A, Chung C. Career Paths of School Administrators in Illinois: Insights from an Analysis of State Data. Santa Monica, CA: RAND, 2004.

[36] Loder, TL, Spillane JP. Is a principal still a teacher? US women administrators' accounts of role conflict and role discontinuity. School Leadership and Management. 2005; 25(3): 263-279.

[37] Açıkalın A, Şişman M, Turan S. Bir İnsan Olarak Okul Müdürü. Ankara, Anı Yayıncılık, 2007.

[38] Lichtman M. Qualitative Research in Education: A User's Guide ( $3^{\text {rd }}$ Ed.). Thousand Oaks, CA: Sage Publication Inc, 2013.

[39] Mertens, DM. Research and Evaluation in Education and Psychology: Integrating Diversity with Quantitative, Qualitative and Mixed Methods ( $3^{\text {rd }}$ Ed.). Thousand Oaks, CA: Sage Publication Inc, 2009.

[40] Bogdan RC, Biklen SK. Qualitative Research for Education: An Instruction to Theory Methods ( $4^{\text {th }}$ Ed.). Pearson International Edition: Boston, 2007.

[41] Yıldırım A, Şimşek H, Sosyal Bilimlerde Nitel Araştırma Yöntemleri, Ankara, Seçkin Yayıncılık, 2005.

[42] Yazıcıŏlu Y, Erdoğan S. SPSS Uygulamalı Bilimsel Araştırma Yöntemleri (3. Baskı). Ankara: Detay Yayıncılık, 2011.

[43] Merriam SB. Qualitative Research: A Guide to Design and Implementation. San Francisco, CA: Jossey- Bass, 2009.

[44] Patton ML. Proposing Empirical Research: A Guide to the Fundementals, Glendale, CA: Pyrczak Publishing, 2010.

[45] Yıldırım A, Şimşek H. Sosyal Bilimlerde Nitel Araştırma Yöntemleri, Ankara, Seçkin Yayıncılık, 2008.

[46] Johnson LA. Why principals quit. Politics and the Principalship. 2005; 21-23.

[47] Volokh A, Snell L. School violence prevention: strategies to keep schools safe (unabridged). Policy Study. 1998; 234:1-86

[48] Brooks MC, Ekkarin S. We still have bombings': School principals and insurgent violence in Southern 
Thailand. International Journal of Leadership in Education. 2015:1-29.

[49] Günbayı İ, Akcan F. Compulsory school principals' opinions on job stress and stressors: A case study. Journal of Teacher Education and Educators. 2013; 2(2): 195-224.

[50] Tamer M. The education and Immigrant Children. Usable Knowledge Connecting Research to Practice, Online

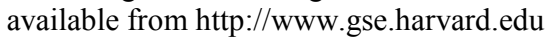

[51] Sobel A, Kugler EG. Building partnership with immigrant parents. Educational Leadership. 2007; 64(6): 62-66.
[52] Can N. The Importance and necessity of forming organizations. Education and Science. 2002; 27(125): 74-78.

[53] Gül H. Çevresel baskı gruplarının okulun genel işleyişine etkileri (Kocaeli-İzmit Örneği). Kocaeli Üniversitesi Sosyal Bilimler Enstitüsü Dergisi. 2006; 11(1): 71-84.

[54] Bayar A, Kerns JH. Undesired behaviors faced in classroom by physics teachers in high schools. Eurasian Journal of Physics and Chemistry Education. 2015; 7(1): 37-45.

[55] Cruickshank DR, Jenkins DB, Metcalf KK. The act of teaching. New York: McGraw $\square$ Hill, 2003. 